OPEN ACCESS

Edited by:

Marianthi Papakosta,

Pfizer, United States

Reviewed by:

Muzamil Ahmad,

Indian Institute of Integrative Medicine

(CSIR), India

Francesco Bellanti,

University of Foggia, Italy

${ }^{*}$ Correspondence:

Zhou Fel

feizhou@fmmu.edu.cn

${ }^{\dagger}$ These authors have contributed equally to this work.

Specialty section: This article was submitted to

Neuropharmacology,

a section of the journa

Frontiers in Neuroscience

Received: 05 October 2017

Accepted: 22 January 2018

Published: 09 February 2018

Citation:

Wu X, Luo P, Rao W, Dai S, Zhang L,

Ma W, Pu J, Yu Y, Wang J and Fei $Z$ (2018) Homer1a Attenuates Hydrogen Peroxide-Induced Oxidative Damage in HT-22 Cells through AMPK-Dependent Autophagy. Front. Neurosci. 12:51. doi: 10.3389/fnins.2018.00051

\section{Homer1a Attenuates Hydrogen Peroxide-Induced Oxidative Damage in HT-22 Cells through AMPK-Dependent Autophagy}

\author{
Xiuquan $\mathrm{Wu}^{1+}$, Peng Luo ${ }^{1 \dagger}$, Wei Rao ${ }^{1,2 \dagger}$, Shuhui Dai ${ }^{1+}$, Lei Zhang ${ }^{1}$, Wenke Ma ${ }^{1,3}$, \\ Jingnan $\mathrm{Pu}^{1}$, Yang $\mathrm{Yu}^{1}$, Jiu Wang ${ }^{1}$ and Zhou Fei ${ }^{1 *}$ \\ 1 Department of Neurosurgery, Xijing Hospital, Fourth Military Medical University, Xi'an, China, ${ }^{2}$ Department of Neurosurgery, \\ PLA Navy General Hospital, Beijing, China, ${ }^{3}$ Department of Neurosurgery, Baoji Center Hospital of Shanxi Province, Baoji, \\ China
}

Neuronal oxidative stress is involved in diverse neurological disorders. Homer1a, as an important member of the Homer family and localized at the postsynaptic density, is known to protect cells against oxidative injury. However, the exact neuroprotective mechanism of Homer1a has not been fully elucidated. Here, we found that Homer1a promoted cell viability and reduced $\mathrm{H}_{2} \mathrm{O}_{2}$-induced $\mathrm{LDH}$ release. The overexpression of Homer1a enhanced autophagy after $\mathrm{H}_{2} \mathrm{O}_{2}$ treatment, which was confirmed by increased expression of LC3II, Beclin-1, and greater autophagosome formation. In addition, we demonstrated that activating autophagy improved cell survival and reduced $\mathrm{H}_{2} \mathrm{O}_{2}$-induced oxidative stress and mitochondrial damage. Moreover, the autophagy inhibitor 3-MA partially prevented the protective effects of Homer1a against oxidative challenge. We also found that the upregulation of Homer1a after $\mathrm{H}_{2} \mathrm{O}_{2}$ treatment increased the phosphorylation of AMPK. Furthermore, the AMPK inhibitor compound $\mathrm{C}$ inhibited Homer1a-induced autophagy and abolished Homer1a-mediated neuroprotection. All the above data suggests that Homer1a confers protection against $\mathrm{H}_{2} \mathrm{O}_{2}$-induced oxidative damage via AMPK-dependent autophagy.

Keywords: Homer1a, hydrogen peroxide, AMPK, autophagy, oxidative stress, mitochondrial dysfunction

\section{INTRODUCTION}

Oxidative stress is an important pathophysiological feature of acute and chronic neurological diseases, including neurodegenerative diseases (Jiang et al., 2016), traumatic brain injury (Rodriguez-Rodriguez et al., 2014), and cerebral ischemia (Amaro et al., 2015). Oxidative stress occurs when the endogenous antioxidant capability of a cell is inadequate to overcome the effects of reactive oxygen species (ROS). $\mathrm{H}_{2} \mathrm{O}_{2}$, a well-established ROS generator, has been observed in nearly all types of oxidative stress, and oxygen radicals spread freely within and beyond cells and tissues (Barbouti et al., 2002). $\mathrm{H}_{2} \mathrm{O}_{2}$-induced oxidative stress can directly attack cellular components, such as lipids, proteins and DNA, and therefore leads to cell death.

Autophagy is primarily a protective process that occurs in response to various stresses. During the autophagy, double-membrane vesicles known as autophagosomes deliver cytosolic macromolecules and damaged organelles into the lysosome for degradation, thereby maintaining 
homeostasis (Bento et al., 2016). Although accumulating studies have highlighted the crosstalk between oxidative stress and autophagy, whether autophagy mitigates or exacerbates oxidative damage is still a controversial issue (Filomeni et al., 2015).

Homer proteins are a group of postsynaptic scaffold proteins that are characterized by a conserved enabled/vasodilatorstimulated phosphoprotein (Ena/VASP) homology 1 (EVH1) domain (Brakeman et al., 1997; Kato et al., 1997). Homerla, as the short variant of Homer proteins, lacks the carboxy-terminal coiled-coil structure involved in the self-multimerization of long Homers (Shiraishi-Yamaguchi and Furuichi, 2007). Due to these structural features, Homerla acts as a dominantnegative protein that disrupts the complexes formed by long Homers and regulates downstream signaling (Xiao et al., 2000). Our previous studies have demonstrated that Homerla protects neurons against various stresses by regulating metabolic glutamate receptors, $\mathrm{N}$-methyl-D-aspartate receptors, and storeoperated calcium entry (Luo et al., 2014; Wang et al., 2015; Rao et al., 2016). We also found that Homerla attenuates $\mathrm{H}_{2} \mathrm{O}_{2}$-induced oxidative stress by reducing ROS accumulation in PC12 cells (Luo et al., 2012). However, the exact associated molecular mechanisms of Homerla against oxidative stress have not been reported. In the present study, we determined the protective effects of Homerla against oxidative stress. We also investigated the effect of Homerla overexpression on autophagy and confirmed the involvement of AMPK in autophagy and Homerla-induced cytoprotection..

\section{MATERIALS AND METHODS}

\section{Antibodies and Reagents}

Antibodies against LC3, P62, Beclin-1, $\beta$-actin, AMPK, and $\mathrm{p}$-AMPK (Thr172), were obtained from Cell Signaling Technology. Antibodies against Homerla were obtained from Synaptic Systems. Rapamycin, STF-62247, compound C, 3-MA, and chloroquine were purchased from Sigma-Aldrich.

\section{Cell Culture}

HT-22 cells (Institute of Biochemistry and Cell Biology, SIBS, CAS.) were grown in DMEM (Gibco, Frederick, MD, USA) plus $10 \%$ fetal bovine serum (Gibco) and $1 \%$ penicillin-streptomycin (Sigma-Aldrich, St. Louis, MO, USA). The cells were cultured in a humidified atmosphere at $37^{\circ} \mathrm{C}$ under $5 \% \mathrm{CO} 2$. Before the experiments, HT-22 cells were seeded in 6-well culture dishes $\left(10^{6}\right.$ per well $)$ and incubated until they reached $70-80 \%$ confluency. Rapamycin (5 $\mu \mathrm{M})$, STF-62247 (10 $\mu \mathrm{M})$, 3-MA $(2 \mathrm{mM})$, chloroquine $(10 \mu \mathrm{M})$, and compound $\mathrm{C}(20 \mu \mathrm{M})$ were added to the cultures for $24 \mathrm{~h}$ before $\mathrm{H}_{2} \mathrm{O}_{2}$ treatment.

\section{Lentivirus Construction and Transfection}

The preparation of lentivirus for the overexpression experiments was performed as previously described (Luo et al., 2014). The lentivirus overexpression system was developed by removing the EGFP open reading frame from the pGC-FU-EGFP-3FLAG construct (GeneChem Co., Shanghai, China) with an AgeI/NheI digestion and replacing this cassette with Homerla cDNA.HT-22 cells were transfected with lentivirus vectors at a multiplicity of infection (MOI) of 30 for $48 \mathrm{~h}$.

\section{Western Blot}

After each treatment, the cells were lysed in RIPA buffer with protease inhibitor cocktail (Roche Applied Bioscience, Indianapolis, IN, USA) and subjected to western blotting as described previously (Rao et al., 2016). Briefly, protein concentrations were assessed with a BCA Kit (Pierce, Rockford, IL, USA), and equivalent amounts of protein $(30 \mu \mathrm{g})$ were separated by $8-15 \%$ SDS-PAGE gels, followed by transfer onto PVDF membranes. The membranes were then soaked in 5\% skim milk in Tris-phosphate buffer containing 0.05\% Tween 20 (TBST) for $1 \mathrm{~h}$ and further incubated overnight at $4{ }^{\circ} \mathrm{C}$ with the appropriate primary antibody (Homer1a 1:1000; LC3II 1:1000; Beclin-1 1:1000; P62 1:8000; $\beta$-actin 1:5000; AMPK 1:1000; p-AMPK 1:1000). After three washes for $8 \mathrm{~min}$ in TBST, the blots were incubated with HRP-conjugated secondary antibodies for 1-2 $\mathrm{h}$. The target protein signal was detected by SuperSignal West Pico Chemiluminescent Substrate (Thermos Scientific). The optical densities of the bands were quantified by ImageJ (Scion Corporation, Torrance, CA, USA).

\section{Measurement of ROS Production}

The intracellular ROS was measured by 2,7dichlorodihydrofluoresceindiacetate ( $\left.\mathrm{H}_{2} \mathrm{DCFDA}\right)$ (Molecular Probe), as previously reported (Luo et al., 2012). HT-22 cells were incubated with $\mathrm{H}_{2}$ DCFDA $(10 \mathrm{mM})$ for $1 \mathrm{~h}$ at $37^{\circ} \mathrm{C}$ in dark and then resuspended in phosphate-buffered saline (PBS). The fluorescence intensity was read with a fluorescence plate reader (excitation wavelength of $480 \mathrm{~nm}$ and an emission wavelength of $530 \mathrm{~nm})$.

\section{Measurement of Lipid Peroxidation}

Malonyldialdehyde (MDA) and 4-hydroxynonenal (4-HNE), two indexes of lipid peroxidation, were detected using a Lipid Peroxidation 4-HNE Assay Kit (Beyotime, Shanghai, China) and a Lipid Peroxidation MDA Assay Kit (Beyotime, Shanghai, China), according to the manufacturer's instructions. The absorbance was read at $450 \mathrm{~nm}$ using a ELISA reader.

\section{Measurement of Mitochondrial Membrane Potential (MMP)}

MMP was monitored using the fluorescent dye rhodamine 123 (Rh 123). Rh 123 was added to cultures to achieve a final concentration of $10 \mathrm{mM}$ for $30 \mathrm{~min}$ at $37^{\circ} \mathrm{C}$ after the HT-22 cells had been treated and washed with PBS. Fluorescence was acquired using a fluorescence plate reader (excitation wavelength of $480 \mathrm{~nm}$, emission wavelength of $530 \mathrm{~nm}$ ).

\section{Measurement of Intracellular ATP}

The intracellular ATP levels were measured using a firefly luciferase based ATP assay kit (Beyotime, China), strictly following the manufacturer's protocol. The ATP levels of each group were calculated as a percentage of the control. 


\section{Immunofluorescence}

HT-22 cells were fixed in $4 \%$ paraformaldehyde for $20 \mathrm{~min}$, washed in PBS, and then permeabilized with $0.2 \%$ Triton $\mathrm{X}$ 100 for $10 \mathrm{~min}$. Next, the cells were incubated with rabbit antiLC3 antibody $(1: 200)$ at $4^{\circ} \mathrm{C}$ overnight, followed by incubation with Alexa 488 donkey-anti-rabbit IgG (1:400) for $2 \mathrm{~h}$ at room temperature. The nuclei were counter-stained with DAPI for 10 min (Sigma). All the images were acquired using a confocal microscope (FV10i, Olympus, Tokyo, Japan) with the same exposure time, light sensitivity and laser power.

\section{Cell Viability Assay}

The cell viability assay was performed using the Cell Counting Kit-8 (CCK-8) (\#CK04; Dojindo, Japan), following the manufacturer's instructions. Normal cells or lentivirus-infected cells were seeded in 96-well plates with 5,000 cells per well. After treatment, $10 \mu \mathrm{l} /$ well of CCK-8 solution was added into each well and incubated for $4 \mathrm{~h}$. The absorbance was measured at $450 \mathrm{~nm}$ using a microplate reader. (Bio-Rad, Hercules, CA, USA).

\section{Lactate Dehydrogenase (LDH) Assay}

The release of $\mathrm{LDH}$ was evaluated using the Cytotoxicity Detection Kitplus (Roche Applied Bioscience, Indianapolis, IN, USA), following the manufacturer's protocol. After subtracting the background values in the medium, the percentage cytotoxicity was calculated with the following equation: $\mathrm{LDH}$ release $(\%$ of $\mathrm{Max})=100 \times$ (experimental value-low control)/(high control-low control). Experimental value, $\mathrm{LDH}$ values in the experimental groups; Low control, $\mathrm{LDH}$ values in the untreated normal cells; High control, the maximum releasable $\mathrm{LDH}$ values in the untreated normal cells.

\section{Tunel Staining}

Apoptosis in HT-22 cells was detected with the terminal deoxynucleotidyl transferase (TdT)-mediated dUTP nickend labeling (TUNEL) In Situ Cell Death Detection Kit (\#11684795910; Roche, Mannheim, Germany). The cells were fixed with freshly prepared $4 \%$ paraformaldehyde for $20 \mathrm{~min}$ at room temperature and permeabilized with $0.2 \%$ Triton $\mathrm{X}-100$ for $5 \mathrm{~min}$. The cells were then incubated with $50 \mu \mathrm{l}$ TUNEL reagent mixture for $60 \mathrm{~min}$ at $37^{\circ} \mathrm{C}$ following the manufacturer's protocol. The images were captured with a fluorescence microscope, the TUNEL-positive cells were counted and the ratio of TUNEL-positive cells/total cells was calculated. DAPI $(10 \mu \mathrm{g} / \mathrm{ml})$ was used to stain nuclei.

\section{Electron Microscopy}

The HT-22 cells were fixed in 2\% paraformaldehyde-2\% glutaraldehyde buffered with $0.1 \mathrm{~mol} / \mathrm{L}$ phosphate buffer at room temperature. The cells were post-fixed with $1 \%$ osmium tetroxide, dehydrated in acetone and immersed in resin. After hardening, the samples were cut into $50 \mathrm{~nm}$ thick slices, stained with lead citrate and observed on an electron microscope.

\section{Statistical Analysis}

All the experiments were performed a minimum of three times. The statistical analyses were conducted using the GraphPad Prism software, version 6.0 (GraphPad, San Diego, CA, USA).
Significance between experiments was assessed by univariate analysis of variance (ANOVA; more than two groups), followed by Bonferroni's multiple comparisons or unpaired $t$-test (two groups).

\section{RESULTS}

\section{Homer1a Protects against $\mathrm{H}_{2} \mathrm{O}_{2}$-Induced Oxidative Injury in HT-22 Cells}

HT-22 cells were exposed to an increasing concentration of $\mathrm{H}_{2} \mathrm{O}_{2}$ $(200,400,600,800,1000 \mu \mathrm{M})$ for $24 \mathrm{~h}$. The results showed that $\mathrm{H}_{2} \mathrm{O}_{2}$ decreased cell viability and induced $\mathrm{LDH}$ release in a dose-dependent manner (Figures 1A,B). An exposure to $600 \mu \mathrm{M}$ $\mathrm{H}_{2} \mathrm{O}_{2}$ for $24 \mathrm{~h}$ was used in the following experiments given that exposure to the cell insult induced nearly $50 \%$ cell death. To investigate the effect of $\mathrm{H}_{2} \mathrm{O}_{2}$ on Homerla expression, HT-22 cells were incubated in the presence of $\mathrm{H}_{2} \mathrm{O}_{2}(600 \mu \mathrm{M})$ for different periods of time (control, 8, 16, and $24 \mathrm{~h}$ ). The results indicated that $\mathrm{H}_{2} \mathrm{O}_{2}$ significantly increased the levels of Homer1a within $24 \mathrm{~h}$ (Figure 1C).

To identify the effect of Homerla on $\mathrm{H}_{2} \mathrm{O}_{2}$-induced oxidative stress, HT-22 cells were transfected with lentivirus carrying Homerla (LV-Homerla) or a negative control lentivirus (LV-NC). Immunoblot analysis showed that lentiviral transduction of LV-Homerla increased the expression of Homerla protein (Figure 1D). After treatment with $\mathrm{H}_{2} \mathrm{O}_{2}$ for $24 \mathrm{~h}$, the viability of HT-22 cells transfected with LV-Homer1a was higher than the cells transfected with LV-NC (Figure 1E). Furthermore, the overexpression of Homerla clearly decreased LDH release after $\mathrm{H}_{2} \mathrm{O}_{2}$ treatment (Figure 1F).

\section{Homer1a Modulates Autophagy in HT-22 Cells Undergoing Oxidative Stress}

To test whether the Homerla regulates autophagy following oxidative stress, we transfected HT-22 cells with LV-Homerla and cultured the cells for 2 days before adding $\mathrm{H}_{2} \mathrm{O}_{2}$. Our results showed that the overexpression of Homerla increased protein levels of LC3II and Beclin-1 and decreased the expression of p62 (Figures 2A-D). The immunofluorescent results indicated that the overexpression of Homerla significantly increased the number of LC3-positive puncta after $\mathrm{H}_{2} \mathrm{O}_{2}$ treatment compared to the LV-NC group (Figures $2 \mathrm{E}, \mathbf{F}$ ). In addition, ultrastructural studies clearly revealed more autophagosomes in the LV-Homerla group after $\mathrm{H}_{2} \mathrm{O}_{2}$ treatment compared to the LV-NC group (Figures 2G,H).

\section{Homer1a Inhibits $\mathrm{H}_{2} \mathrm{O}_{2}$-Induced Cell Injury by Upregulating Autophagy}

To determine the role of autophagy in $\mathrm{H}_{2} \mathrm{O}_{2}$-induced oxidative damage, we evaluated cell injury after HT-22 cells were treated with $\mathrm{H}_{2} \mathrm{O}_{2}$ and pharmacological agents that modulated autophagy (Figure 3A). The results indicated that rapamycin, a classical inducer of autophagy, reduced the number of TUNEL-positive cells and decreased LDH release after oxidative stress (Figures 3B-D). To identify whether Homer1a conferred protection through modulation of autophagy, HT-22 cells 
A

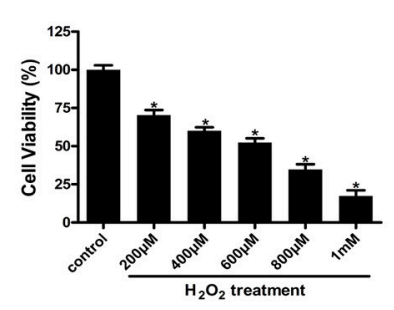

D
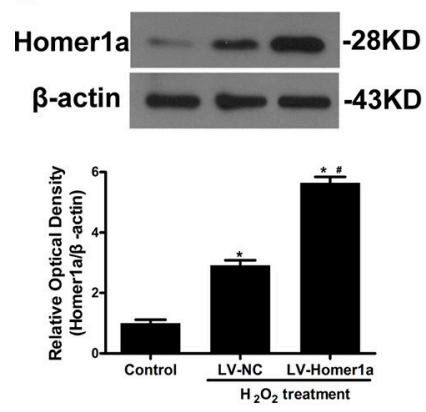

B

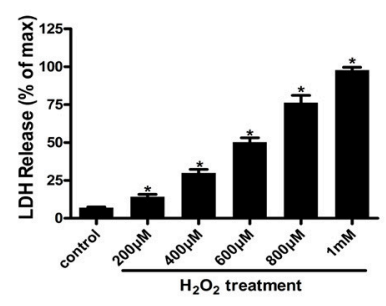

E

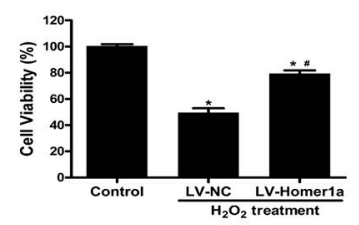

C

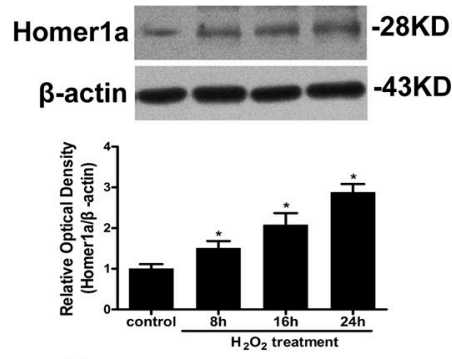

$\mathbf{F}$

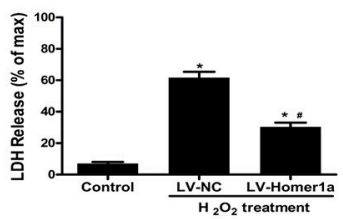

FIGURE 1 | Homer1a protects against $\mathrm{H}_{2} \mathrm{O}_{2}$-induced oxidative injury in $\mathrm{HT}$-22 cells. $\mathrm{HT}$-22 cells were exposed to different concentrations of $\mathrm{H}_{2} \mathrm{O}_{2}$ for $24 \mathrm{~h}$. Cell

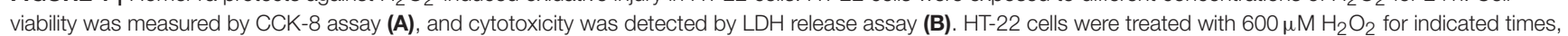
the expression of Homer1a was determined by Western blot (C). HT-22 cells were transfected with LV-NC or LV-Homer1a for $48 \mathrm{~h}$ and exposed to $\mathrm{H}_{2} \mathrm{O}_{2}(600 \mu \mathrm{M})$ for $24 \mathrm{~h}$. Homer1a protein level was detected by Western blot after treated with or without $\mathrm{H}_{2} \mathrm{O}_{2}$ (D). Cell viability and cytotoxicity were measured in presence or absence of $\mathrm{H}_{2} \mathrm{O}_{2}$ (E,F). The data were expressed as means \pm SEM from five experiments. ${ }^{\star} P<0.05$ vs. Control, $\# P<0.05$ vs. LV-NC group.

were transfected with LV-Homerla and/or treated with the autophagy inhibitor 3-MA. The results showed that the increased expression of LC3II induced by Homerla overexpression was decreased by 3-MA (Figure 3E). Moreover, treatment with 3-MA or chloroquine (CQ), another autophagy inhibitor, partially reversed the protective effects of Homerla against $\mathrm{H}_{2} \mathrm{O}_{2}$-induced injury (Figures 3F-H).

\section{Autophagy Is Involved in the Homer1a-Mediated Protection against $\mathrm{H}_{2} \mathrm{O}_{2}$-Induced Oxidative Stress and Mitochondrial Damage}

To assess the relationship between autophagy, $\mathrm{H}_{2} \mathrm{O}_{2}$-induced oxidative stress and mitochondrial damage, HT-22 cells were pretreated with rapamycin or STF-62247, another autophagy activator before $\mathrm{H}_{2} \mathrm{O}_{2}$ treatment. The results showed that rapamycin and STF-62247 both significantly reduced $\mathrm{H}_{2} \mathrm{O}_{2}$ induced ROS production, lipid peroxidation (MDA and 4-HNE), loss of MMP and ATP production (Figures 4A-E). To further investigate the role of Homerla-induced autophagy in regulating oxidative stress and mitochondrial function, HT-22 cells were transfected with LV-Homerla or LV-NC and treated with 3-MA and $\mathrm{H}_{2} \mathrm{O}_{2}$. We observed that $\mathrm{H}_{2} \mathrm{O}_{2}$-induced ROS production and lipid peroxidation decreased in HT-22 cells transfected LV-Homerla (Figures 4A-C). Moreover, the overexpression of Homerla prevented the $\mathrm{H}_{2} \mathrm{O}_{2}$-induced loss of MMP and reduction of ATP production (Figures 4D,E). However, the Homerla-mediated protection against $\mathrm{H}_{2} \mathrm{O}_{2}$-induced oxidative stress and mitochondrial damage were partially abolished by 3-MA (Figures 4A-E).

\section{The Homer1a/AMPK/Autophagy Pathway Reduces $\mathrm{H}_{2} \mathrm{O}_{2}$-Induced Oxidative Stress}

To further clarify the molecular mechanisms through which Homerla mediates autophagy and protection, we tested whether Homerla protects HT-22 cells through the AMPK pathway. The results indicated that the overexpression of Homerla markedly increased the phosphorylation of AMPK after $\mathrm{H}_{2} \mathrm{O}_{2}$ treatment (Figure 5A). In addition, the increased levels of p-AMPK induced by Homerla was partially prevented by the AMPK inhibitor compound C (Figure 5A). The western blot results showed that the increased expression of Beclin-1 and LC3II induced by Homerla overexpression after oxidative stress was reversed by compound $\mathrm{C}$ treatment (Figures 5B-D). Moreover, the Homer1a-induced decreased $\mathrm{LDH}$ release, ROS production and increase in MMP levels upon $\mathrm{H}_{2} \mathrm{O}_{2}$ challenge were partially abolished by compound $\mathrm{C}$, suggesting that $\mathrm{AMPK}$ was involved in Homerla-induced protection (Figures 5E-G).

\section{DISCUSSION}

In the present study, we revealed that Homerla confers protection against oxidative stress by regulating autophagy in 


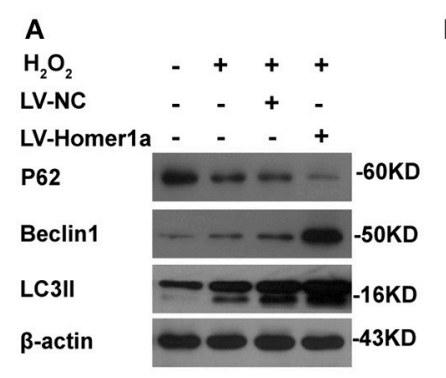

E

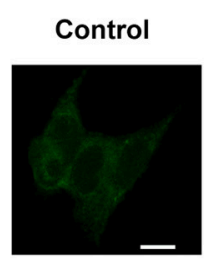

G

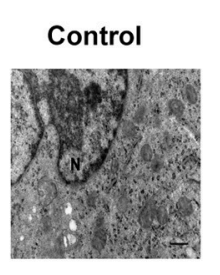

B

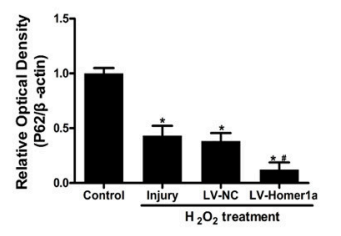

$\mathrm{H}_{2} \mathrm{O}_{2}$ treatemnt
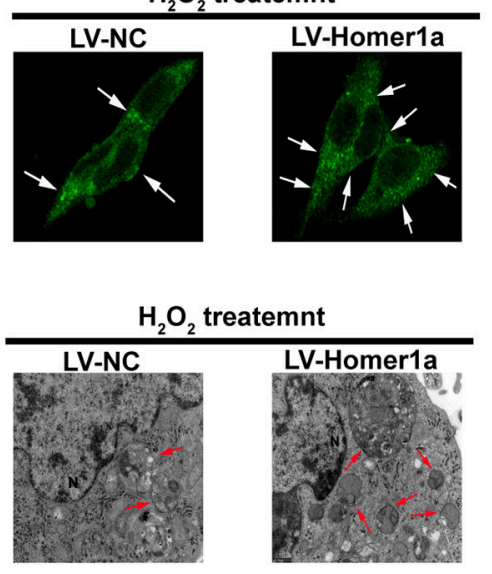

C

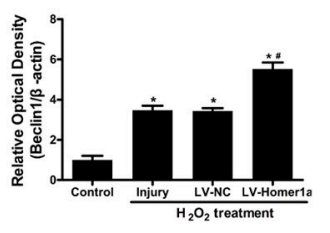

D

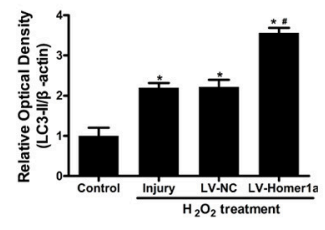

$\mathbf{F}$

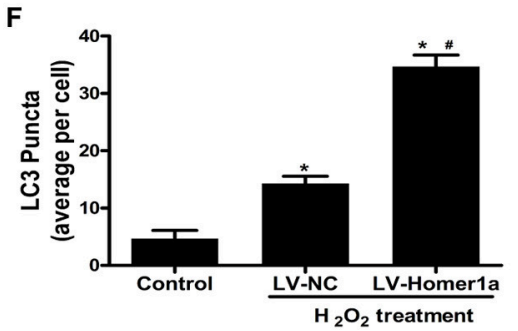

H

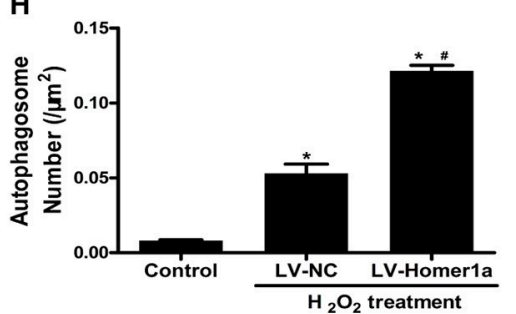

FIGURE 2 | Homer1a regulates autophagy following oxidative stress. HT-22 cells were transfected with LV-NC or LV-Homer1a for $48 \mathrm{~h}$ and exposed to $\mathrm{H}_{2} \mathrm{O}_{2}$ $(600 \mu \mathrm{M})$ for $24 \mathrm{~h}$. The expression of LC3II, Beclin1 and P62 at $24 \mathrm{~h}$ after $\mathrm{H}_{2} \mathrm{O}_{2}$ treatment were detected by Western blot analysis (A-D). LC3II was also detected with Immunofluorescence staining at $24 \mathrm{~h}$ after $\mathrm{H}_{2} \mathrm{O}_{2}$ treatment $\mathbf{( E )}$ ), and the number of LC3 puncta (arrows) were calculated (F). Scale bar $=10 \mu \mathrm{m}$. $\mathrm{HT}$-22 cells were observed by electron microscopy at $24 \mathrm{~h}$ after $\mathrm{H}_{2} \mathrm{O}_{2}$ treatment $\mathbf{( G )}$, and the number of autophagosomes (red arrows) were calculated $(\mathbf{H})$. Scale bar $=500 \mathrm{~nm}$. $\mathrm{N}$ : nucleus. The data were expressed as means \pm SEM from five experiments. ${ }^{*} P<0.05$ vs. Control, $\# P<0.05$ vs. LV-NC group.

HT-22 cells. First, we observed that the overexpression of Homerla attenuated $\mathrm{H}_{2} \mathrm{O}_{2}$-induced oxidative injury. Second, it was determined that the protective functions of Homerla were associated with activation of autophagy. Lastly, the AMPK pathway was responsible for the regulation of autophagy induced by Homerla.

Homerla, as an immediate early gene (IEG), functions directly at the synapses (Serchov et al., 2016). In general, Homerla appears to be an important regulator of activity-induced remodeling at synaptic structures (Inoue et al., 2007). Previous studies have shown that activation of Homerla improved neuronal survival after acute brain injury, such as traumatic neuronal injury, cerebral ischemia, and excitotoxic challenge (Luo et al., 2014; Fei et al., 2015; Wang et al., 2015). In line with these studies, our results indicated that the levels of Homerla protein in HT-22 cells increased after $\mathrm{H}_{2} \mathrm{O}_{2}$ treatment in a time-dependent manner. The overexpression of Homerla significantly increased cell viability and decreased $\mathrm{LDH}$ release after oxidative stress, which strongly suggested that Homerla might be cytoprotective against oxidative stress.

Autophagy is a catabolic process occurring in response to multiple forms of cellular stress, such as nutrient deprivation, hypoxia, and intracellular pathogens (Kroemer et al., 2010). It is well accepted that oxidative stress, as the converging point of these stimuli, is the primary intracellular signal transducer that sustains autophagy (Filomeni et al., 2015). Intriguingly, enhanced autophagy is considered both a type of cell death and a pro-survival mechanism upon oxidative stress. In our in vitro model, autophagy activitors, rapamycin and STF-62247 both reduced ROS production, lipid peroxidation, and mitochondrial dysfunction after $\mathrm{H}_{2} \mathrm{O}_{2}$ treatment. These results were consistent with a previous study showing that the upregulation of autophagy with rapamycin in differentiated, rotenone-treated SH-SY5Y cells preserved cell viability (Pan et al., 2009). These results indicated that autophagy is beneficial for cells against oxidative stress. Conversely, recent studies found that treatment with 3-MA protected HT-22 cells against glutamate-induced oxidative stress (Yang et al., 2017). The inconsistency between our results and previous studies might partially be attributed to different models and time points.

According to our results, Homerla is an important regulator of autophagy under oxidative stress conditions. Our previous study indicated that Homerla protected 

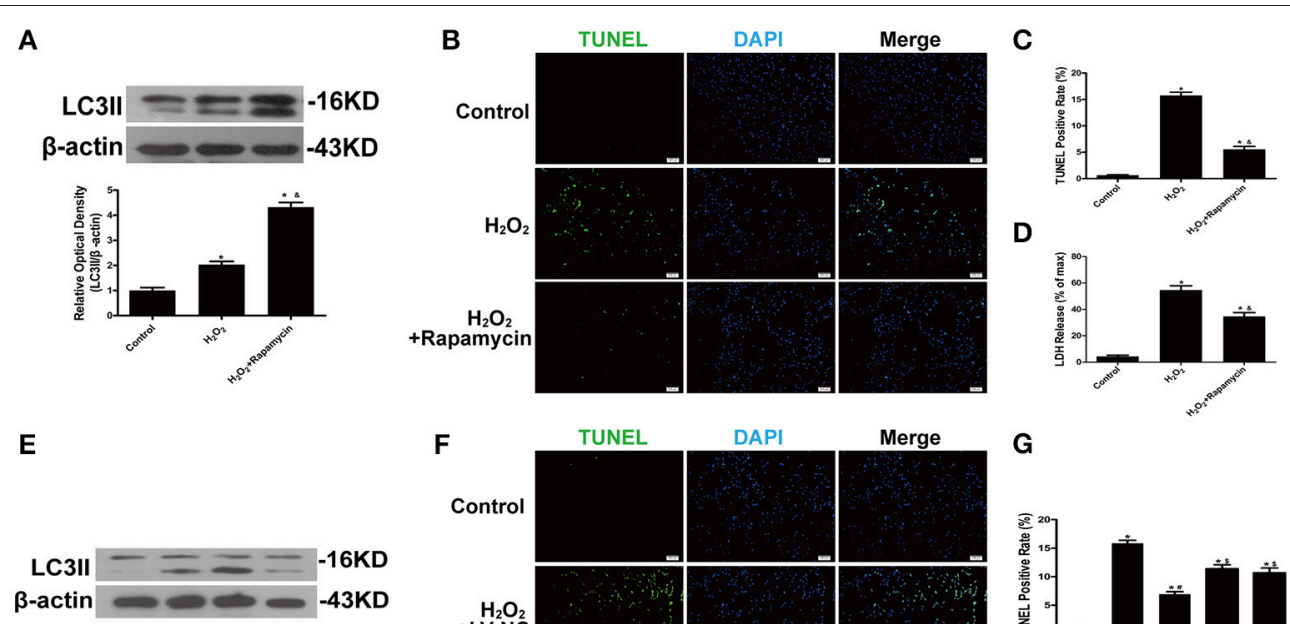

$\mathbf{F}$

F
Control

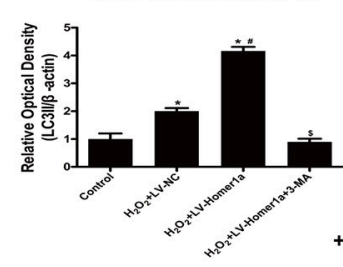

43KD

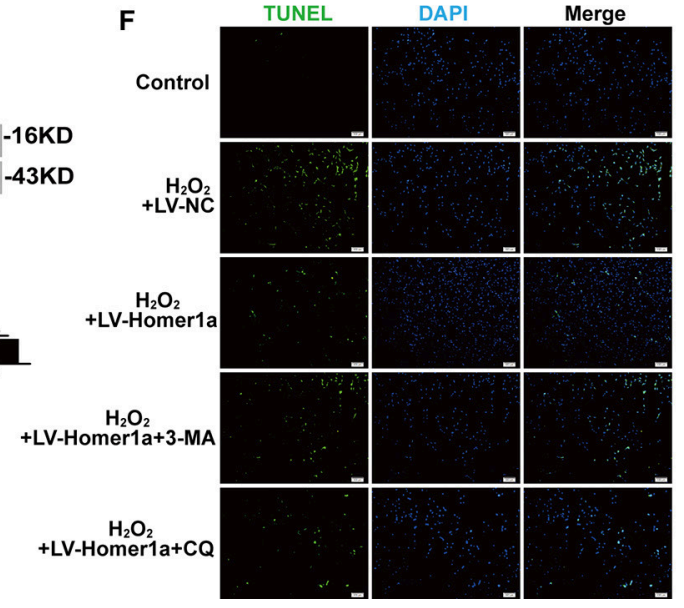

G

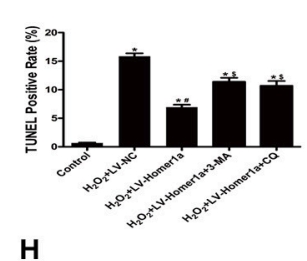

H

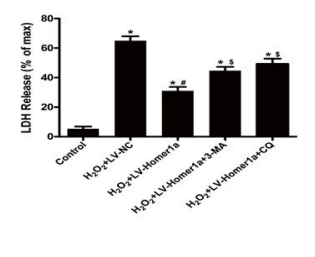

FIGURE 3 | Homer1a inhibits $\mathrm{H}_{2} \mathrm{O}_{2}$-induced cell injury by upregulating autophagy. $\mathrm{HT}$-22 cells were treated with rapamycin (5 $\left.\mu \mathrm{M}\right)$ for $24 \mathrm{~h}$ then $\mathrm{H}_{2} \mathrm{O}_{2}$ applied for $24 \mathrm{~h}$. The expression of LC3II was determined by Western blot (A). Scale bar $=100 \mu \mathrm{m}$. Apoptotic cell death was measured by TUNEL staining (B,C), and cytotoxicity was detected by LDH release assay (D). HT-22 cells were transfected with LV-NC or LV-Homer1a for $48 \mathrm{~h}$. After transfection, the cells were treated with 3-MA ( $2 \mathrm{mM})$ or $\mathrm{CQ}(10 \mu \mathrm{M})$ for $24 \mathrm{~h}$ then $\mathrm{H}_{2} \mathrm{O}_{2}$ applied for $24 \mathrm{~h}$. The expression of LC3II was determined by Western blot (E). Scale bar = 100 $\mu \mathrm{m}$. Apoptotic cell

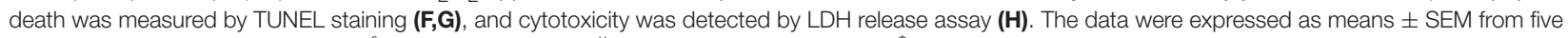
experiments. ${ }^{*} P<0.05$ vs. Control, ${ }^{\&} P<0.05$ vs. $\mathrm{H}_{2} \mathrm{O}_{2}$, ${ }^{\# P} P 0.05$ vs. $\mathrm{H}_{2} \mathrm{O}_{2}+$ LV-NC, ${ }^{\$} P<0.05$ vs. $\mathrm{H}_{2} \mathrm{O}_{2}+\mathrm{LV}-\mathrm{Homer1a}$.

against NMDA-induced neuronal injury by disassembling NR2B-PSD95-nNOS complexes and reducing the membrane distribution of NMDARs (Wang et al., 2015). Importantly, it is well accepted that autophagy machinery is robustly induced in cultured neurons subjected to NMDA treatment (Sadasivan et al., 2010). Therefore, the relationship between Homerla and autophagy is deserving of attention. Our present results suggest that Homerla overexpression markedly increased the expression of LC3II and Beclin1, as well as LC3-positive puncta and the number of autophagosomes after $\mathrm{H}_{2} \mathrm{O}_{2}$ treatment. Moreover, our previous study proved that the overexpression of Homerla protected against $\mathrm{H}_{2} \mathrm{O}_{2}$-induced oxidative stress by reducing ROS production and the loss of MMP and ATP production (Luo et al., 2012). However, we found that autophagy inhibitor 3-MA abrogated the Homerla-mediated protection against $\mathrm{H}_{2} \mathrm{O}_{2}$-induced oxidative stress and mitochondrial damage. Taken together, our results strongly demonstrated that Homerla protected against $\mathrm{H}_{2} \mathrm{O}_{2}$-induced oxidative injury by inducing autophagy.

Another issue to be considered is how Homerla interacts with the autophagy pathway. We found that the overexpression of Homerla increased the phosphorylation of AMPK, which can trigger autophagy to coordinate cell growth and metabolism (Mihaylova and Shaw, 2011). Moreover, AMPK has a pivotal role in the interplay between oxidative stress and autophagic machinery (Filomeni et al., 2015). Previous studies have shown that Homerla can attenuate oxidative injury through storeoperated calcium entry (SOCE), which can also be regulated by AMPK (Lang et al., 2013; Rao et al., 2016). Intriguingly, our results showed that the Homer1a-induced increase in p-AMPK levels was partially reversed by treatment with compound C. Accordingly, the enhanced autophagy and neuroprotection induced by Homerla were abolished by compound C. These data indicate that Homerla stimulated the activity of AMPK and increased the autophagy rate, thereby attenuating $\mathrm{H}_{2} \mathrm{O}_{2}$-induced injury.

In conclusion, oxidative stress-induced cell damage is common in the context of neurological diseases. According to our results, Homerla can protect against oxidative stress through AMPK-dependent autophagy activation, providing a new perspective on the protective role of Homerla. However, little is known regarding the effect of Homerla on autophagy flux and mitophagy. Further investigations on the link between Homerla and autophagy signaling 

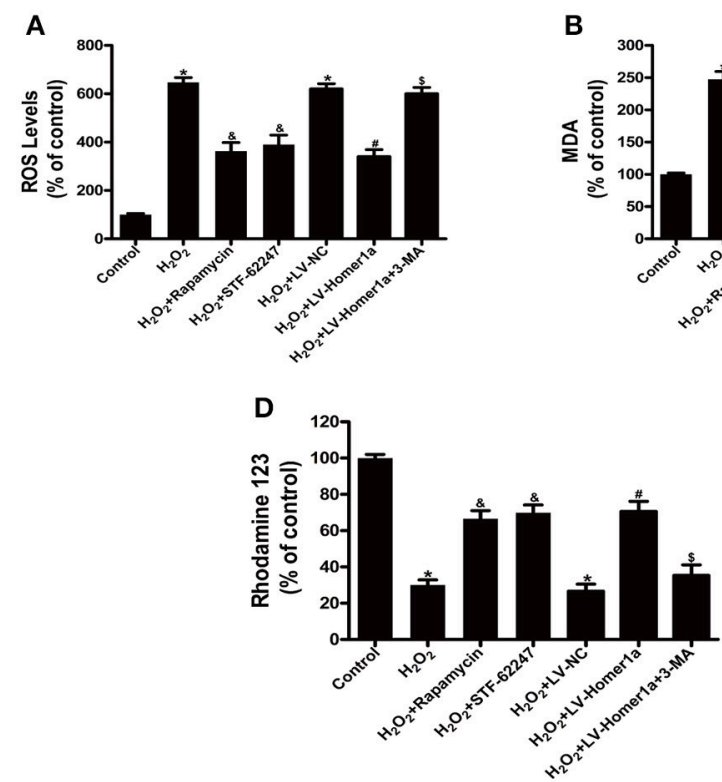
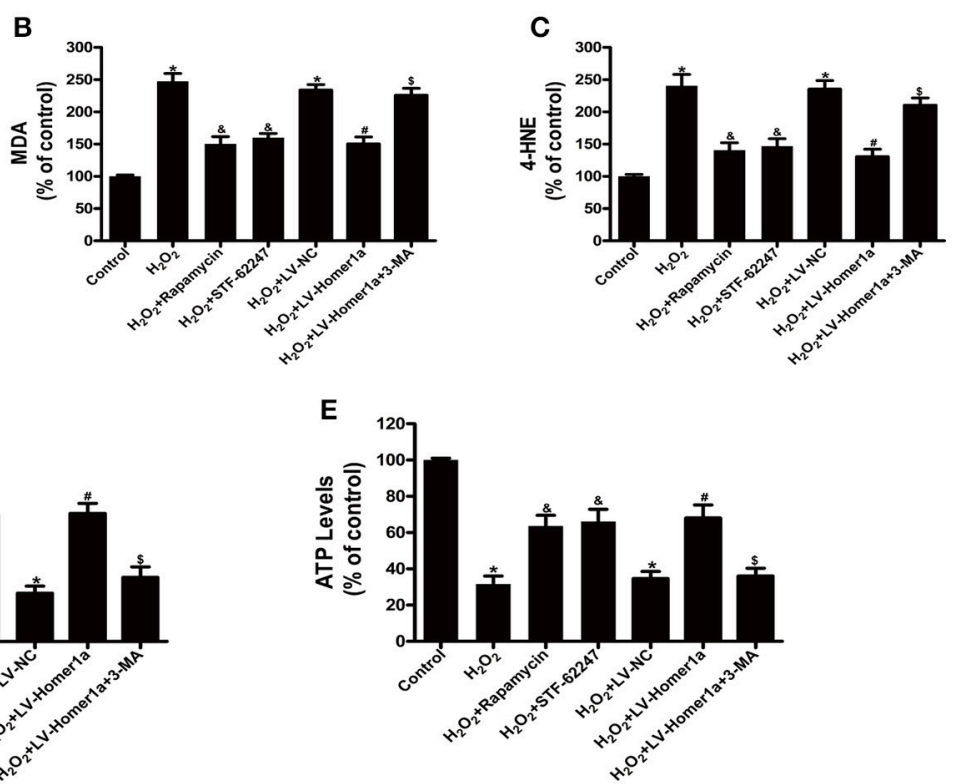

FIGURE 4 | Autophagy is involved in the Homer1a-mediated protection against $\mathrm{H}_{2} \mathrm{O}_{2}$-induced oxidative stress and mitochondrial damage. $\mathrm{HT}$-22 cells were treated with rapamycin $(5 \mu \mathrm{M})$ or STF-62247 $(10 \mu \mathrm{M})$ for $24 \mathrm{~h}$ then $\mathrm{H}_{2} \mathrm{O}_{2}$ applied for $24 \mathrm{~h}$. ROS production, lipid peroxidation, MMP and ATP were assayed (A-E). $\mathrm{HT}-22$ cells were transfected with LV-NC or LV-Homer1a for $48 \mathrm{~h}$. After transfection, the cells were treated with $3-\mathrm{MA}(2 \mathrm{mM})$ for $24 \mathrm{~h}$ then $\mathrm{H}_{2} \mathrm{O}_{2}$ applied for $24 \mathrm{~h}$. ROS production, lipid peroxidation, MMP and ATP were assayed (A-E). The data were expressed as means $\pm \mathrm{SEM}$ from five experiments. ${ }^{\star} P<0.05$ vs. Control, ${ }^{\circledR} P<0.05$ vs. $\mathrm{H}_{2} \mathrm{O}_{2}$, $\# P<0.05$ vs. $\mathrm{H}_{2} \mathrm{O}_{2}+$ LV-NC, $\$ P<0.05$ vs. $\mathrm{H}_{2} \mathrm{O}_{2}+$ LV-Homer1a.

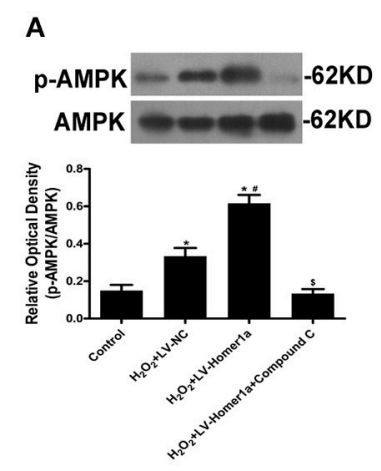

E

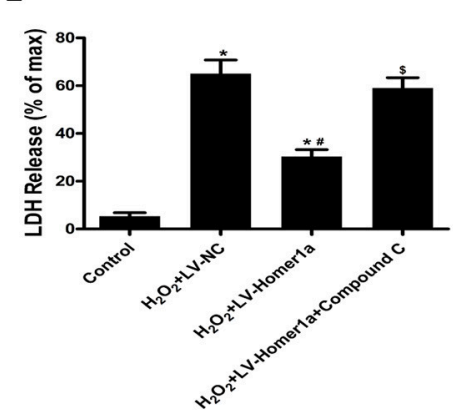

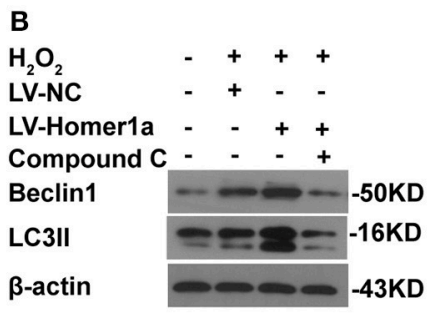

C D
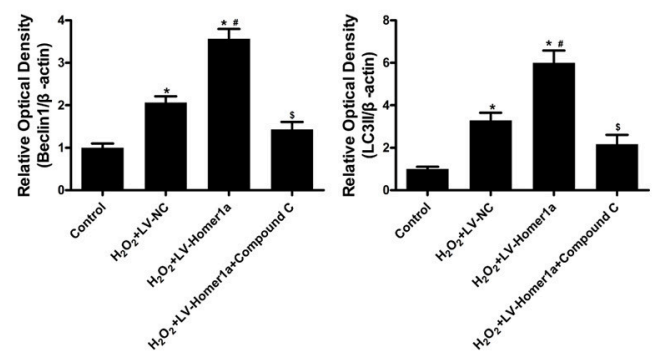

F

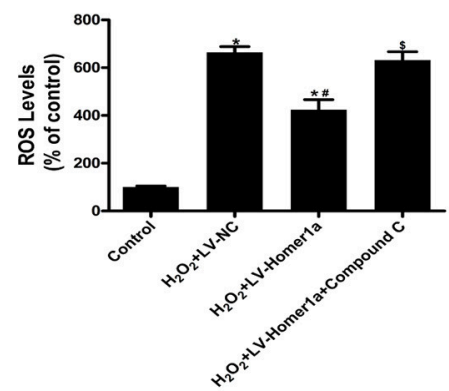

G

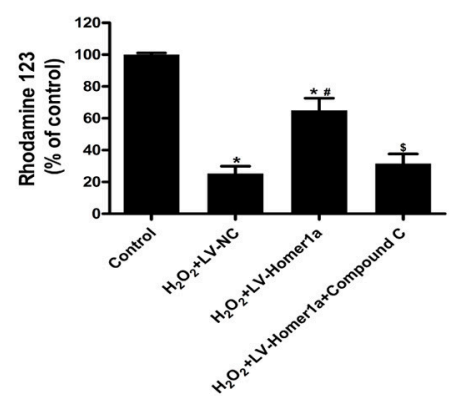

FIGURE 5 | The Homer1a/AMPK/autophagy pathway reduces $\mathrm{H}_{2} \mathrm{O}_{2}$-induced oxidative stress. HT-22 cells were transfected with LV-NC or LV-Homer1a for $48 \mathrm{~h}$. After transfection, the cells were treated with compound $\mathrm{C}(20 \mu \mathrm{M})$ for $24 \mathrm{~h}$ then $\mathrm{H}_{2} \mathrm{O}_{2}$ applied for $24 \mathrm{~h}$. The expression of p-AMPK, AMPK, Beclin1 and LC3II were detected by Western blot analysis (A-D). Cytotoxicity was detected by LDH release assay (E). ROS production and MMP were assayed (F,G). The data were expressed as means \pm SEM from five experiments. ${ }^{\star} P<0.05$ vs. Control, $\# P<0.05$ vs. $\mathrm{H}_{2} \mathrm{O}_{2}+\mathrm{LV}-\mathrm{NC},{ }^{\$} P<0.05$ vs. $\mathrm{H}_{2} \mathrm{O}_{2}+\mathrm{LV}$ - Homer1a. 
would provide a better understanding of neurological diseases.

\section{AUTHOR CONTRIBUTIONS}

XW and ZF: designed the study; XW, PL, WR, and SD: performed the experiments; LZ, WM, and JP: analyzed the data and prepared the figures; YY and JW: contributed reagents or materials; XW and PL: wrote the manuscript; ZF: helped to revise the manuscript.

\section{REFERENCES}

Amaro, S., Llull, L., Renú, A., Laredo, C., Perez, B., Vila, E., et al. (2015). Uric acid improves glucose-driven oxidative stress in human ischemic stroke. Ann. Neurol. 77, 775-783. doi: 10.1002/ana.24378

Barbouti, A., Doulias, P. T., Nousis, L., Tenopoulou, M., and Galaris, D. (2002). DNA damage and apoptosis in hydrogen peroxide-exposed Jurkat cells: bolus addition versus continuous generation of $\mathrm{H}_{(2)} \mathrm{O}_{(2)}$. Free Radic. Biol. Med. 33, 691-702. doi: 10.1016/S0891-5849(02)00967-X

Bento, C. F., Renna, M., Ghislat, G., Puri, C., Ashkenazi, A., Vicinanza, M., et al. (2016). Mammalian autophagy: how does it work? Annu. Rev. Biochem. 85, 685-713. doi: 10.1146/annurev-biochem-060815-014556

Brakeman, P. R., Lanahan, A. A., O'Brien, R., Roche, K., Barnes, C. A., Huganir, R. L., et al. (1997). Homer: a protein that selectively binds metabotropic glutamate receptors. Nature 386, 284-288.

Fei, F., Li, J., Rao, W., Liu, W., Chen, X., Su, N., et al. (2015). Upregulation of Homerla promoted retinal ganglion cell survival after retinal ischemia and reperfusion via interacting with Erk pathway. Cell. Mol. Neurobiol. 35, 1039-1048. doi: 10.1007/s10571-015-0198-2

Filomeni, G., De Zio, D., and Cecconi, F. (2015). Oxidative stress and autophagy: the clash between damage and metabolic needs. Cell Death Differ. 22, 377-388. doi: $10.1038 /$ cdd.2014.150

Inoue, Y., Udo, H., Inokuchi, K., and Sugiyama, H. (2007). Homerla regulates the activity-induced remodeling of synaptic structures in cultured hippocampal neurons. Neuroscience 150, 841-852. doi: 10.1016/j.neuroscience.2007.09.081

Jiang, T., Sun, Q., and Chen, S. (2016). Oxidative stress: a major pathogenesis and potential therapeutic target of antioxidative agents in Parkinson's disease and Alzheimer's disease. Prog. Neurobiol. 147, 1-19. doi: 10.1016/j.pneurobio.2016.07.005

Kato, A., Ozawa, F., Saitoh, Y., Hirai, K., and Inokuchi, K. (1997). vesl, a gene encoding VASP/Ena family related protein, is upregulated during seizure, long-term potentiation and synaptogenesis. FEBS Lett. 412, 183-189. doi: 10.1016/S0014-5793(97)00775-8

Kroemer, G., Mariño, G., and Levine, B. (2010). Autophagy and the integrated stress response. Mol. Cell 40, 280-293. doi: 10.1016/j.molcel.2010.09.023

Lang, F., Münzer, P., Gawaz, M., and Borst, O. (2013). Regulation of STIM1/Orai1dependent Ca2+ signalling in platelets. Thromb Haemost. 110, 925-930. doi: 10.1160/TH13-02-0176

Luo, P., Chen, T., Zhao, Y., Xu, H., Huo, K., Zhao, M., et al. (2012). Protective effect of Homer 1a against hydrogen peroxide-induced oxidative stress in PC12 cells. Free Radical Res. 46, 766-776. doi: 10.3109/10715762.2012.678340

Luo, P., Chen, T., Zhao, Y., Zhang, L., Yang, Y., Liu, W., et al. (2014). Postsynaptic scaffold protein Homer 1a protects against traumatic brain injury via regulating group I metabotropic glutamate receptors. Cell Death Dis. 5:e1174. doi: 10.1038/cddis.2014.116

\section{FUNDING}

The work was supported by National Natural Science Foundation of China (Nos. 81430043, 81771239, 81771322).

\section{ACKNOWLEDGMENTS}

We thank Junli Huo, Juan Li, Xiaoyan Chen, and Yufen Shi for technical assistance.

Mihaylova, M. M., and Shaw, R. J. (2011). The AMPK signalling pathway coordinates cell growth, autophagy and metabolism. Nat. Cell Biol. 13, 1016-1023. doi: 10.1038/ncb2329

Pan, T., Rawal, P., Wu, Y., Xie, W., Jankovic, J., and Le, W. (2009). Rapamycin protects against rotenone-induced apoptosis through autophagy induction. Neuroscience 164, 541-551. doi: 10.1016/j.neuroscience.2009. 08.014

Rao, W., Peng, C., Zhang, L., Su, N., Wang, K., Hui, H., et al. (2016). Homerla attenuates glutamate-induced oxidative injury in HT-22 cells through regulation of store-operated calcium entry. Sci. Rep. 6:33975. doi: $10.1038 /$ srep33975

Rodriguez-Rodriguez, A., Egea-Guerrero, J. J., Murillo-Cabezas, F., and CarrilloVico, A. (2014). Oxidative stress in traumatic brain injury. Curr. Med. Chem. 21, 1201-1211. doi: 10.2174/0929867321666131217153310

Sadasivan, S., Zhang, Z., Larner, S. F., Liu, M. C., Zheng, W., Kobeissy, F. H., et al. (2010). Acute NMDA toxicity in cultured rat cerebellar granule neurons is accompanied by autophagy induction and late onset autophagic cell death phenotype. BMC Neurosci. 11:21. doi: 10.1186/1471-220 2-11-21

Serchov, T., Heumann, R., van Calker, D., and Biber, K. (2016). Signaling pathways regulating Homerla expression: implications for antidepressant therapy. Biol. Chem. 397, 207-214. doi: 10.1515/hsz-2015-0267

Shiraishi-Yamaguchi, Y., and Furuichi, T. (2007). The Homer family proteins. Genome Biol. 8:206. doi: 10.1186/gb-2007-8-2-206

Wang, Y., Rao, W., Zhang, C., Zhang, C., Liu, M. D., Han, F., et al. (2015). Scaffolding protein Homerla protects against NMDA-induced neuronal injury. Cell Death Dis. 6:e1843. doi: 10.1038/cddis.2015.216

Xiao, B., Tu, J. C., and Worley, P. F. (2000). Homer: a link between neural activity and glutamate receptor function. Curr. Opin. Neurobiol. 10, 370-374. doi: 10.1016/S0959-4388(00)00087-8

Yang, Y., Luo, P., Xu, H., Dai, S., Rao, W., Peng, C., et al. (2017). RNF146 inhibits excessive autophagy by modulating the Wnt- $\beta$-Catenin pathway in glutamate excitotoxicity injury. Front. Cell Neurosci. 11:59. doi: 10.3389/fncel.2017.00059

Conflict of Interest Statement: The authors declare that the research was conducted in the absence of any commercial or financial relationships that could be construed as a potential conflict of interest.

Copyright (C) $2018 \mathrm{Wu}$, Luo, Rao, Dai, Zhang, Ma, Pu, Yu, Wang and Fei. This is an open-access article distributed under the terms of the Creative Commons Attribution License (CC BY). The use, distribution or reproduction in other forums is permitted, provided the original author(s) and the copyright owner are credited and that the original publication in this journal is cited, in accordance with accepted academic practice. No use, distribution or reproduction is permitted which does not comply with these terms. 